\title{
Fighting corruption - a philosophical approach
}

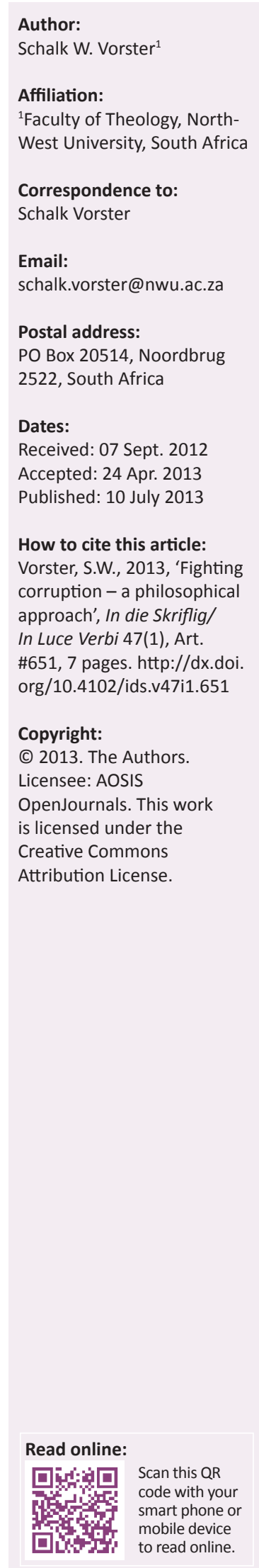

Corruption has reached astounding proportions in South Africa. The purpose of this article is to contribute to philosophical approaches aimed at combating corruption. In considering punishment for acts of corruption the most common approach is based on the philosophical theory of consequentialism, which allows only consideration of the consequences of corrupt acts. Ideally, cognisance should be taken of the norms in question, especially those norms demanding the judicious execution of obligations. It was, however, found that the Kantian categorical imperative presupposes an ideal rational society. The imperative has to be 'softened' by also allowing for enquiry about the corruptor's personal circumstances, in the light of Christ's love commandment. This article highlights the most prominent attributes of two important philosophical theories applicable to the study of corruption, namely utilitarianism (a variant of consequentialism) and deontology. It is argued that qualified deontological and utilitistic approaches hold the best promise to curb corruption in the long run. The conclusion is that the state will urgently have to attend to the social context by revitalising programmes of 'social renewal', based on effective application of the law, the provision of adequate education and the eradication of poverty. There is also an urgent need for the 'moral renewal' of the entire population, focused on Christian values, operationalised within the context of the South Africa of today. Herein lies a massive task for the church.

Die stryd teen korrupsie - 'n filosofiese benadering. Korrupsie het verstommende afmetings in Suid-Afrika aangeneem. Die doel van hierdie artikel is om 'n bydrae te lewer tot filosofiese benaderings wat daarop gemik is om korrupsie te bestry. By die oorweging van strawwe vir korrupte dade word die mees algemene benadering gebaseer op die teorie van konsekwensialisme, wat slegs die gevolge van korrupte dade oorweeg. Ideaal-gesproke behoort ook kennis geneem te word van die norme wat ter sprake is, veral dié norme wat die getroue nakoming van pligte vereis. Daar is egter gevind dat die Kantiaanse kategoriese imperatief ' $n$ ideale rasionele gemeenskap veronderstel. Die imperatief moet dus 'versag' word deur, in die lig van Christus se liefdesopdrag, plek te maak vir oorwegings in verband met die korrupte agent se persoonlike omstandighede. Die studie is uitgevoer deur 'n oorsig van die belangrikste standpunte van twee filosofiese teorieë, naamlik utilitarisme ('n variant van konsekwensialisme) en deontologie te gee. Daar is aangevoer dat gekwalifiseerde deontologiese en utilitaristiese benaderings belofte inhou om korrupsie op die langtermyn te beteuel. Die gevolgtrekking was dat die staat dringend aandag moet skenk aan die sosiale konteks deur die inwerkingstelling van 'n proses van 'sosiale vernuwing', gebaseer op die effektiewe toepassing van die wet, die voorsiening van voldoende onderwys en die bestryding van armoede. Daar is ook 'n dringende behoefte aan die 'morele vernuwing' van die bevolking, met die fokus op Christelike waardes, geoperasionaliseer vir die Suid-Afrika van vandag. Hierin lê 'n groot taak vir die kerk.

\section{Introduction}

Corrupt behaviour has the dishonest acquisition of some form of advantage as its basis and is widely considered an important ethical issue.

Corruption in various forms has been with humankind from the earliest times. In the present time corruption is rampant and occurs in multiple manifestations. It is a ubiquitous phenomenon intensified by the worldwide expansion of trade, the existence of global crime syndicates, the expansion of international aid to underdeveloped countries, the internet, and by governments with weak prosecuting systems. The role of the state (or rather agents of the state), whilst not the only arena for the perpetration of corruption, is certainly a major factor in Africa where weak governments are the rule rather than the exception. In South Africa in particular, corruption has grown into a major problem. It is affecting all levels of government and a large part of the private sector, annually costing the country billions of Rand and corroding the moral fabric of 
society (Vorster 2012:133; Du Plessis \& Breedt 2013:2). In some communities corruption is experienced as directly contributing to poverty (Aleixo 2011:64; Du Plessis \& Breedt ibid:6).

This paper is an attempt to elucidate the true nature of corruption by means of a philosophical approach in which both deontological and consequential ethics will be considered. It will be argued that corruption, in essence, amounts to the abandonment or perversion of specific obligations and that deontology possibly points the way to redemption.

\section{Forms of corruption}

Vorster (2012) has extensively reviewed the occurrence of private and public sector corruption in South Africa. Because of its pervasive nature, an adequate formulation of a definition of corruption is almost impossible. Andvig and Fjeldstad (2001:5-6) report a few definitions, but find them only useful in the classification of the different types of corruption. The World Bank (1997:8) states that 'corruption is the abuse of public power for private benefit (or profit)'. The deficiency of this definition is immediately apparent in the light of the pervasive nature of corruption alluded to above. Miller and Blacker (2005:112) conclude that, in the light of failures of analytical definitions to adequately describe corruption, it is tempting to try to sidestep the problem of providing a theoretical account of the concept of corruption by simply identifying corruption with specific legal and/or moral offences.

Andvig and Fjeldstad (2001:5) typify the different forms of corruption as particular state-society relationships, distinguishable in political corruption and bureaucratic corruption. They also make two further distinctions, namely individual-collective corruption and 'upward extraction/ downward redistribution'. Andvig and Fjeldstad's classification fails to address corruption in all its manifestations. Various taxonomies of corruption are provided in the literature, for example by Van der Walt (2003:401) and Spence, Miller and Roberts (2005:2). It seems pointless to simply add offences to the existing lists. There is bound to be disagreement in relation to any such list, quite apart from the fact that the development of technology probably adds new forms of corruption almost on a daily basis.

Superimposed on the evasive concept of corruption is the fact that it is frequently 'softened' by certain local socio-cultural customs. Andvig and Fjeldstad (2001:54) cite the practice of guanxi [gift giving] in China and blat [the use of personal networks and informal contacts to obtain goods and services in short supply and to find a way around formal procedures] in Russia. In Africa, ethnocentrism, nepotism and/or political affiliations are frequently the driving forces behind acts of corruption (Van der Walt 2003:406). However, different forms of favouritism are found all over the world. Maestripieri (2012) describes a particular form of nepotism that is rife in academic circles in Italy. Influential academics (known as baroni) regulate admission to graduate programmes and academic posts to ensure that family members and children of friends or politicians are awarded places, frequently to the detriment of more suitably qualified candidates. Maestripieri views nepotism from within an evolutionistic worldview and declares that it has natural origins and aims to maintain the own DNA. Nepotism is a classic example of collective self-interest (Spence et al. 2005:74).

As there are numerous examples of wrongful acts not considered corruption, although abhorrent on moral or ethical grounds, a clear distinction between a corrupt act and other immoral acts is essential. It is therefore necessary to explore those characteristics of corruption that can be considered as uniquely typifying it in order to arrive at the essence of corruption.

\section{The essence of corruption}

At the outset, it is necessary to consider that corruption always involves an appointed task that is not carried out, or carried out in a perverted way, in order to gain something of value wrongfully. A study of corruption will therefore require an analysis of the deontological aspects of corrupt actions.

Miller and Blacker (2005:115-116) point out that, in order to not revert to subsuming corruption under the general notion of immoral actions, one has to stress that it is a causal phenomenon having ramifications stretching much further than the corrupt act per se, in view of its involvement of other persons and/or institutions. They present the following assumptions regarding corruption:

- An action is corrupt if it morally degrades a person or an institution (e.g. perverts, destroys or subverts honesty or integrity), regardless if any laws or rules have been broken.

- Those who are corrupted and those who corrupt differ in respect of their intentions and beliefs concerning the corrupting effect of their actions.

The authors point out that those who are corrupted are not always blameless, as collusion is frequently evident, in which case the parties involved each fulfils the role of corruptor and corrupted. The corruptor also corrupts himself, although probably unintentionally. The corrupt character of the corruptor is revealed when he offers a bribe, even if it is subsequently rejected by the would-be corrupted.

A complicating factor with regard to the study of acts of corruption is that different communities have different conceptions of right and wrong - what the one may regard as corrupt, another might regard as normal honest practice. When the state, a company or an institution is involved in acts of corruption, it is frequently found that perfectly honest employees are drawn into a nexus of corrupt practices by their employer, but that they do not feel personally accountable. An important characteristic of corruption, namely its 
propensity to engender the type of 'atmosphere' in which it can prosper, must count as one of its most disturbing traits (cf. Vorster 2012).

An act of corruption establishes a special type of bond between the corruptor and the corrupted, and is initiated by the corruptor. It is also important to recognise that an act of corruption somewhat blurs the distinction between the corruptor and the corrupted as they are both drawn into a web of unethical or immoral behaviour. The corruptor, in a sense, seizes control of the morality of the corrupted, separating him from ethically and morally acceptable obligations by coercing him to abandon those obligations from which he is isolated. The corruptor uses the corrupted as means to an end. The corrupted is compelled to embrace a deontology based on mistrust, deceit, dread, avariciousness and hate, thereby relinquishing a deontology based on love, respect, reliability, honesty and respectability. Secrecy is such an important aspect of corruption that many governments, in true Machiavellian style, pass legislation in order to ensure that corrupt actions are kept under wraps.

It is concluded that the pernicious nature of corruption can be summarised by its degrading effects on people and its tendency to create an environment that is continually being made more 'corruption-friendly' if corruption is allowed to fester unabated.

The relationship established by an act of corruption shifts the focus to the duties and the actions of the respective agents, but also to the corrective actions considered by the relevant authorities. What ought they have done, what did they in fact do and what are the consequences of their actions? These questions are questions of normative ethics and the problems will now be viewed from both a utilitist and a deontological perspective. Utilitarianism accepts that an act is only right (good) if it results in the maximum amount of good, referred to as 'happiness' (Mill 1907:16).

\section{Approaches to corruption and combating corruption}

The focus on acts of corruption may mainly be placed 'before the act' by deontologists and 'after the act' by utilitarians. Utilitarians maintain that people must act morally in ways that will produce the best consequences. Deontologists rely on adherence to certain rules in order to militate against acts of corruption. Deontology as a rule-based normative ethical theory illuminates the moral dimension of human activities, especially those that concern human obligations and responsibilities. Deontologists see punishment for criminal deeds as a means of deterrence, whilst utilitarianism views punishment from the retributive angle. Both these approaches demand special attention in a study of corruption.

\section{The utilitarian approach}

Because the utilitarian approach places emphasis mainly on the consequences of acts, it can be inferred that a person involved in an act of corruption will tend to pay scant attention to any laws and rules forbidding corruption. An action is considered right if it results in happiness - not the agent's own happiness, but 'the greatest amount of happiness altogether' (Mill 1907:16). Actions are right if they tend to promote happiness and wrong if they do the reverse (Mill ibid:9). This leads Owen (2011:6) to conclude: 'If corruption and maladministration neither promote pleasure nor prevent pain for the general good they are not morally wrong from a utilitarian point of view.'

Turning to the punitive aspect pertaining to the corrupt act, it must be pointed out that it is of essence reactive in nature. As a consequence of the utilitarian style of reasoning, the resultant action by the authorities must be focused on inducing the maximum measure of total 'happiness'. This should include the perpetrator, as well as society at large. Any deliberation in respect of combating corruption will ask three general questions (LaFollette 2007:25):

- Which consequences should be counted?

- How much weight or consideration should be given to those that do count?

- How should those considerations be used in deliberation?

Some consequences of corruption have minimal moral effects and will therefore not feature prominently in any deliberations, whilst others may have widespread and serious implications. Personal circumstances during the execution of the corrupt act, as well as its contingent consequences, will have to be considered in the utilitarian approach. LaFollette writes (2007:26): 'The factors that determine whether a consequence counts also determine its nature: does it advance or set back someone's significant interest?' Consequently, the determination of the weight of an act of corruption requires careful study and, in the worst case, might be highly subjective.

Act-utilitarianism and rule-utilitarianism are two variants of the utilitist view of the moral actions of persons (LaFollette 2007:28). In act-utilitarianism no prior reasons are to be included when considering punishment for acts of corruption. It suffers from the weakness that no normative rules, laws, etc. may be taken into consideration. The deficiency of this position is partly alleviated by rule-utilitarianism, which will consider rules or norms, as well as consequences, in deliberations of morality. The fear exists that courts of law, for example, could subjectively devalue rules by ascribing to them a lower weight (for example when 'corruption-friendly' local customs are involved) and also by narrowing the scope of the consequences of a corrupt act.

The establishment of the balance between rules and consequences in rule-utilitarianism is not always easy. Hodgson (1967:71-72) partly concedes that no form of utilitarianism can adequately account for the importance of certain moral rules. He maintains that one form of ruleutilitarianism, namely 'individual-rule-utilitarianism', ensures proper consideration by judges. He believes that individual-rule-utilitarianism is more in accord with the 
convictions of most persons as to the importance of moral rules and the duty to obey them (Hodgson ibid:6). This rule is explained by him as follows (Hodgson ibid:63): 'An act is right if and only if it is in accordance with the agent's acceptance of which as a personal rule would have best consequences ...' The disadvantage of this notion is the large element of arbitrariness introduced as a result of the absence of any norm that transcends human consciousness. The above considerations cast a shadow on the appropriateness of any utilitist approach to the combating of corruption.

\section{Deontic approaches}

A basic distinction between the utilitarian approach and the deontological approach to the adjudication of matters concerning corruption is that the judge will look in different directions, depending on the style of reasoning. As alluded to earlier, the view in the utilitarian style is to the future and in the deontic to the past (cf. Rawls 2000:481). Central to the deontic argument is the existence of certain rules, be they commandments, laws, codes of practice or 'standing orders', which act as moral compasses. This approach rests on Kant's rational categorical imperative as an absolute rule for moral behaviour (Kant 2002:229). Deontologists therefore ascribe to strict rule-based morals when dealing with others. Blanchard (1961) points out that:

Deontologists have shown a fidelity to actual moral judgment that is probably closer than that of any other contemporary school. They have argued with great force that moral judgments are really judgments, not expressions of feelings only, and here - for whatever it is worth - common sense is undoubtedly on their side. (p. 159)

A deontological approach to corruption will therefore require careful attention to moral norms and their relation to conscience in the human mind.

\section{Deontology and conscience}

The doctrine of conscience has had a long history of development (Prins 1937:196-244). The Stoics amalgamated the main ideas of Heraclitus of Ephesus (540-475 BC) with the Doctrine of Ideas of Plato and referred to the Logos [law] as 'god' who instils ideas in humans by means of logoi spermatikoi (rational seeds), which was seen as the origin of conscience. The padres largely accepted this doctrine, which they based on John 1. In the Middle Ages Alexander of Hales (1185-1245) first wrote extensively about conscience. He distinguished two parts of the soul: pars animae sensibilis [the senses] and pars animae rationalis [The rational or spiritual competencies]. Under the pars animae rationalis, Hales placed the conscience (synteresis) (Prins ibid:206). The synteresis provides knowledge to and propels man, and cannot be extinguished. Also the will belongs to the synteresis and is differentiated in natural will (voluntas naturalis) and reason-based will (voluntas deliberativa) (Prins ibid:210). It appears that he distinguishes between an unchangeable part (synteresis) and a changeable part (conscientia). Further development occurred in the Scholastic period, with Aquinas exerting the most influence in both Protestant and Roman Catholic ethics. Prins comes to the conclusion that synteresis and conscientia would become the poles within which the doctrine of conscience would evolve in future (Prins ibid:211).

The concepts of synteresis and conscientia were taken over by the Reformers who gave them somewhat different meanings. But Prins remarks that the traditional and the later reformational concepts cannot be disentwined entirely (Prins 1937:248). Calvin does, however, introduce new elements. In a powerful sentence, Calvin summarises the most important elements of the reformational concept of conscience (Calvin 1957a): ${ }^{1}$

That there exists in the human mind, and indeed by natural instinct, some sense of Deity, we hold to be beyond dispute, since God himself, to prevent any man from pretending ignorance, has endued men with some idea of his Godhead, the memory of which he constantly renews and occasionally enlarges, that all to a man, being aware that there is a God, and that he is their Maker, may be condemned by their own conscience when they neither worship him nor consecrate their lives to his service. (p. 43)

Calvin therefore sees the following attributes of conscience (cf. Prins 1937:250):

- It is associated with common grace (universis).

- Common grace is continuously being granted up to the present day (assidue renovans and novas subinde guttas instillat).

- Common revelation does not occur in a sensational way (subinde instillat).

- The main content of common revelation is that man is aware that there is a God (quandam sui numinis intelligentiam).

- All men are condemned by their own conscience (suo ipsorum testimonio damnentur). The conscience therefore acts as an accusatory conscience.

Prins (1937:254) discerns Calvin's association of common grace and natural law with 'conscience', but believes that he actually refers to synteresis in the last instance, ascribing a meaning to it that differs from that used in the Middle Ages. Without explicitly using the word synteresis, Prins (ibid:255) finds an implicit description of the concept in the Institutes: 'Hence this distinction between honourable and base actions God has not only engraven on the minds of each, but also often confirms in the administration of his providence' (Calvin 1957b:75). Prins maintains that the synteresis is the seat of norms. He finds that the synteresis doctrine teaches us to distinguish between a firm and invariable foundational norm (synteresis), and a variable and fallible element (conscience) (Prins ibid:520, 462).

In the present time, both the terms synteresis and conscientia have fallen into disuse, leaving only 'conscience' (Greek: suneidesis), which includes both universal rules and particular cases (Reese 1980:103). It appears, however, that the basic

1.'Quemdam inesse humanae menti, et quidem naturali instinctu, divinitatis sensum extra controversiam ponimus; si quidem, ne quis ad ignorantiae praetextum confugeret, quandam sui numinis intelligentiam universis Deus ipse indidit, cuius memoriam assidue renovans, novas subinde guttas instillat: ut quum ad unum memoriam assidue renovans, novas subinde guttas instillat: ut quum ad unum
omnes intelligent Deum esse, et suum esse opificem, suo ipsorum testimonio damnentur quod non et illum coluerint, et eius voluntati vitam suam consecrarint.. 
ideas pertaining to these concepts are still latent in modern ethical philosophy.

It seems reasonable to conclude that part of a person's morality has a natural basis and is shaped only by cultural influences (Pope 2007:257). It is therefore not surprising that peoples with different cultural backgrounds have different conceptions of right or wrong, especially if they are not amenable to adhere to specific moral codes engraved in the synteresis. These conceptions eventually coalesce into a shared worldview, or consensus gentium, namely the universal, or very wide, agreement between peoples in respect of certain customs and beliefs (Mautner 2005:119).

Conscience depends partly on accurate information, and partly on conditioning by the environment and by habits (Pierce 1955:127). As Blanchard (1961) puts it:

It ... is the deposit of parental example, of the instruction of teachers, and of the pressure of society, themselves in turn the product of centuries of experimentation. Conscience is thus the voice of our own hitherto accepted ideal, recording its yes or no to a proposed line of conduct. It does not in general argue; it simply affixes its seal or enters its protest. (p. 33)

Christian philosophers view conscience (in a wider sense) as an innate understanding of God's truth, and it influences the distinguishing and evaluation of personal acts. Perry (2005:16) discerns four important aspects of conscience: '(1) its relation to the inner man; (2) its relation to the understanding; (3) its task of bearing witness; and (4) its influence on personal judgment'. He continues (Perry ibid):

The conscience's association with the inner man and its affiliation with the understanding relate to the nature of the conscience, while the conscience's task of bearing witness and its responsibility in personal judgment relate to its role. (p. 17)

To the Christian, conscience is that faculty of man that monitors his obedience to the will of God. A clear awareness of conscience may be present, even in persons who profess that they do not believe in God. Conscience seems to point to a transcosmic law that anticipates God and can bring about shame, even when our actions have the approval of public opinion. If we act unethically, our conscience can cause feelings of loneliness and abandonment, leaving us defenceless before God (Stoker 1967:309-319).

Wallace (2012:1) considers the following scenarios relating to the deontic structure of morality and the demands that morality make on human acts in general:

- Reasons that are normative for all agents, without reference to the personal preferences or interests.

- Reasons that are weighty to such an extent that they override normative considerations.

Wallace (2012) attempts to discover the differences between 'aspirational' normativity and 'deontic' normativity with respect to the above-mentioned scenarios, and finds it necessary to allude to the social context within which the individual's deliberation takes place. The notion of the social context leads Wallace to believe that reciprocal (or bipolar) normative structures form the key to the understanding of the idea of deontic structure. He traces discretional (aspirational) normativity to the local social context, and deontic normativity to reciprocal structures between individuals. The application of reason in such a structure gives it the character of an obligation, in contradistinction to the 'free standing' forms of aspirational normativity. It means that 'we have a certain latitude to ignore or discount aspirational reasons, of a kind we do not have when it comes to reasons that exhibit deontic structure'. Discretional (aspirational) normativity is dictated by the local social context (the 'here and now'), and is a human construct without any compelling 'normative power'. Deontic normativity seems to be more resistant to social influence and is based on reciprocal structures between individuals (Wallace ibid:29).

The influence of the local social context (the 'here and now') is an important aspect in the study of corruption. As previously alluded to, if corruption is allowed to continue unchallenged, the social context itself is corrupted, resulting in the devaluation of 'discretional normativity', and thereby engendering a greater measure of tolerance towards corruption. Every corrupt transactional relationship established becomes a node in the web of corruption. It does, however, seem that Wallace is somehow shifting the responsibility for crimes (including acts of corruption) from the humans involved to the external circumstances existing during these acts. This horizontal stance is also discernible in his notion of the origin of deontic normativity as formed by a nexus of individual human relationships.

Stoker (1970) distinguishes between 'general deontics' and 'contingent deontics'. The former relates, according to Stoker, to general norms and laws, as exemplified by 'amongst others, the general norms (or laws) of thought, language and art, of rights, ethics and religion' Stoker (ibid:183). They are binding on all men for all time and under all circumstances. General deontics (norms and laws) have their origin in the creative will of God. General deontic norms are timeless and belong to the order of creation (Stoker ibid:183). 'Contingent' deontics determine what man ought to do 'here and now'. Stoker points out that, in all his tasks, man has a deontic choice whether he will submit himself to the deontics concerned or disobey them. Stoker (ibid:183) continues: 'Human freedom is realised on account of his choice between his ... possibilities (or tasks) and by his submission (obedience) to the deontic determinants concerned'. He also states that 'all the general deontics and all the contingent deontics together are, furthermore, interrelated and entwined' (Stoker ibid:183). In addition, contingent deontics are neither deductible from, nor reducible to general deontics and they are subject to general deontics. Contingent deontics have their origin in the governing will of God. The author points out that man can make choices subject to both general deontics and contingent deontics. Man may choose to obey or disobey both 'general' and 'contingent' deontic norms. His freedom resides in obedience of deontic norms and, conversely, disobedience (as, for example, manifested in acts of corruption) leads to loss of freedom and enslavement in a secret nexus of dishonesty. The 'normative power' of contingent deontics 
is subject to personal conceptions of right or wrong. Stoker (ibid:182) states that 'on account of man's freedom of choice for his actions ... man is, and must be, accountable for his actions'.

\section{Summation}

The upshot of the above treatment of the conscience is that synteresis-conscience is the receptacle for timeless norms inscribed into the hearts of all people and which God granted to all in terms of his common grace. Paul writes (Rm 2):

Indeed, when Gentiles, who do not have the law, do by nature things required by the law, they are a law for themselves, even though they do not have the law. They show that the requirements of the law are written on their hearts, their consciences also bearing witness, and their thoughts sometimes accusing them and at other times even defending them. (vv. 14-15)

These norms are sometimes inhibited by the sinner, but can never be extinguished.

In contradistinction to the synteresis-conscience, the conscientia-conscience can be influenced by various factors. In the Bible, the conscientia-conscience is variously depicted as weak (1 Cor 8:10; $1 \mathrm{Tt}$ 4:1-5; Heb 5:14), defiled (1 Tt 1:15; Ac 4:12), seared (1 Tt 4:1-2; Heb 3:8-13), evil (Heb 10:22; 9:7-13; Mt 26:35; 69-75), a source of good (Ac 23:1; 1 Pt 3:21), etc. Paul writes in Titus 1:

$[T]$ o those who are corrupted and do not believe, nothing is pure. In fact, both their minds and consciences are corrupted. They claim to know God, but by their actions they deny him. They are detestable, disobedient and unfit for doing anything good. (v. 15)

In the context of the present study, the contribution of the social context to the corruption of the conscience is considered of prime importance.

\section{Anti-corruption strategies}

'In the arsenal of techniques advocated for fighting corruption the ethical causes are often ignored or are mentioned only in passing - as if they are peripheral to the phenomenon' (Van der Walt 2003:407). The question of morality and corruption is a personal and a communal problem, as Spence et al. (2005) point out:

The successful combating of crime and corruption presupposes a moral community: a community of people who for the most part try to do what is morally right and to avoid doing what is morally wrong, because they desire or believe that they ought to do what is right and to avoid doing what is wrong. (p. 197)

How is such a society established if it has been largely infiltrated by a corrupt culture? In any programme of moral renewal, the 'education' and activation of the conscience of every individual will obviously play a pivotal role.

A recurring theme in the development of the closely related concepts of 'conscience' and 'morality' is their dual natures. On the one hand there is their more permanent manifestation, variously referred to as 'general deontics', 'Christianised conscience' or 'deontic reasons', and on the other hand a variable manifestation typified as 'contingent deontics', 'aspirational reasons' or 'contingent deontics'.
There is no free movement of ideas from 'aspirational reasons' to 'deontic' ones simply by the imposition of arbitrary sanctions or penalties in the event of non-compliance (cf. Wallace 2012:16). It means that the cascading of ethical conduct is essentially a 'top-down' process. Ideas flow from the ethical principles residing in the synteresis to the consentia, and not vice versa. Applied to the problem of corruption, it means that if a supra-cultural worldview based on universal ethical concepts is absent, the passing of legislation to try and prevent corruption, or the imposition of heavy fines to punish perpetrators, will be of limited value.

Efforts by utilitarians to devise anti-corruption systems of necessity always fail to deal with their main problem, namely that utilitarianism in any form is by its very nature focused on reaction. It mainly deals with the problem 'after the act' and it has been shown that utilitarian approaches do not appear very effective as a deterrent for perpetrators of corruption. (Habtemichael 2009:98) writes: 'Most traditional anti-corruption strategies focus on dealing with symptoms rather than causes and emphasise stern punishment, salary increment to public servants or establishing anticorruption commissions.' He suggests that anti-corruption strategies should be based on ICTs (information and communication technologies), 'because corruption and anti-corruption strategies are complex social phenomena' (Habtemichael ibid:267). The approaches referred to in the above quotations are based on typical act-utilitarian reasoning, namely that the success of a particular act depends solely on its consequences. In South Africa it is found that limited success is achieved by the mere application of the law. Vorster (2012:140) writes: 'The common law system did not prevent the corruption during the Apartheid era and did not reduce corruption after the transition to a full democracy.' The troubling question that arises is: Why should corrupt persons associate punishment with crime unless they live in a society in which offenders are caught and punished regularly? Surely, if the state fails in its obligations, it can be accused of complicity in the creation of a corrupting 'atmosphere'.

The success of punishment, both as retribution and as deterrent, is highly dependent on several factors, namely the efficiency of the relevant judicial system and the correctional services, as well as the local perceptions regarding corrupt activities. A deontological approach, by virtue of its normbased focus, tends to be pro-active.

The unqualified deontological approach, however, is not without special problems in a developing country with huge education and income inequalities. Deontology has, inescapably, inherited the basic rational idealistic characteristics of the Kantian categorical imperative. Kant's imperative presupposes an ideal society in which everyone acts rationally. In practice, a deontological approach to corruption in a hugely unequal society creates the very real danger that, with the focus firmly set solely on the observance of laws and rules, the corrupt human is objectified and the problem 'solved' by meting out the appropriate desert. The 
specific personal reasons behind the actions of a corrupt person are seldom investigated. His action may have been prompted by abject poverty, lack of appropriate experience in a position of trust, peer pressure, et cetera. Dewey (1988) writes:

By killing an evil-doer or shutting him up behind stone walls, we are able to forget both him and our part in creating him. Society excuses itself by laying blame on the criminal; he retorts by putting the blame on early bad surroundings, the temptation of others, the lack of opportunities, and the persecutions of officers of the law. Both are right, except in the wholesale nature of their recriminations. No amount of guilt on the part of the evil-doer absolves us from the responsibility for the consequences on him and others of our way of treating him, or from our continuing responsibility for the conditions under which persons develop perverse habits. (p. 20)

The heartless application of unqualified deontological theory in an unequal society will have limited success in eradicating corruption.

From the above it seems that a two-pronged effort is required in order to combat corruption. In this effort, the best of two worlds, that of the deontologist and that of the utilitarian, will have to be brought to bear on the problem. Firstly, there is an urgent need for the 'moral renewal' of the entire population; focused on Christian norms and values and operationalised within the context of the South Africa of today. It will have to amount to the activation of a critical conscience to maintain high moral values at all times. Herein lies a massive task for the church (cf. Vorster 2012; Du Plessis \& Breedt 2013). Concomitantly, the state will have to urgently attend to the social context by instigating 'social renewal', based on effective application of the law and education. It is, however, clear that there is no quick solution to the problem.

\section{Conclusion}

Each act of corruption contributes to building an 'atmosphere', or social context, that becomes progressively more corruption-friendly. In South Africa, the prevailing poverty, weak government institutions and an eroded moral fibre must be seen against the backdrop of a strong materialistic worldview. Whilst anti-corruption measures are important and should continually be improved, the only effective way to combat corruption is by a long-term programme aimed at 'moral renewal' of the entire population. This programme should be run by the state with specific inputs by the church and should focus on the inculcation of time-tested values and practices based on honesty, integrity and responsibility. In this programme, attention should be given to biblical deontic norms and those aspects of utilitarian theory applicable to a civilised society.

\section{Acknowledgements Competing interests}

The author declares that he has no financial or personal relationship(s) that may have inappropriately influenced him in writing this article.

\section{References}

Aleixo, J.D., 2011, 'The alleviation of poverty in Mozambique - A Christian ethical perspective', MA Thesis, Faculty of Theology, North-West University, Potchefstroom.

Andvig, J.C. \& Fjeldstad, O-H., 2001, 'Corruption - A review of contemporary research', Chr. Michelsen Institute for Development Studies and Human Rights Report, viewed 16 May 2013, from http://www.cmi.no/publications/2001/rep/ r2001-7.pdf|

Blanchard, B., 1961, Reason and goodness, George Allen \& Unwin, London.

Calvin, J., 1957a, Institutes of the Christian religion, vol. 1, transl. H. Beveridge, Eerdmans, Grand Rapids, Ml.

Calvin, J., 1957b, Institutes of the Christian religion, vol. 2, transl. H. Beveridge, Eerdmans, Grand Rapids, MI.

Dewey, J., 1988, The middle works, 1899-1924, human nature and conduct, Southern Illinois University Press, Carbondale, I.L.

Du Plessis, A.L. \& Breed, G., 2013, 'A possible solution for corruption in South Africa with the church as initiator: A practical theological approach', HTS Teologiese
Studies/Theological Studies 69(2), Art. 1298, viewed 12 April 2013, from http:// Studies/Theological Studies 69 (2),
dx.doi.org/10.4102/hts.v69i2.1298

Habtemichael, F.S., 2009, 'Anti-corruption strategies in the South African public sector', PhD dissertation, School of Public Management and Planning, University of Stellenbosch.

Hodgson, D.H., 1967, Consequences of utilitarianism - A study in normative ethics and legal theory, Clarendon Press, Oxford.

Kant, I., 2002, Groundwork for the metaphysics of morals, transl. A. Zweig, Oxford University Press, Oxford. (Original work published in 1785).

LaFollette, H., 2007, The practice of ethics, Blackwell, Oxford.

Maestripieri, D., 2012, Games primates play: An undercover investigation of the evolution and economics of human relationships, Basic Books, New York. (Read in abstract form only).

Mautner, T., 2005, Dictionary of philosophy, 2nd edn., Penguin, London.

Mill, J.S., 1907, Utilitarianism, Longmans, Green \& Co, London.

Miller, S. \& Blacker, J., 2005, Ethical issues in policing, Ashgate Publishing, Aldershot.

Owen, N., 2011, 'Chapter IX: The nature and role of applied ethics in the public sector' Council for Research in Values and Philosophy (CRVP), viewed 06 April 2013, from http://www.crvp.org/book/Series02/II-7/chapter_ix.htm

Perry, G.W., 2005, 'The conflict between liberty of conscience and church authority in today's evangelical church', MA Thesis, Reformed Theological Seminary, Orlando, F.L.

Pierce, C.A., 1955, Conscience in the New Testament, SCM Press, London.

Pope, S.J., 2007, Human evolution and Christian ethics, Cambridge University Press, Cambridge. http://dx.doi.org/10.1017/CBO9780511550935

Prins, P., 1937, Het geweten, Meinema, Delft.

Rawls, J., 2000, 'Two concepts of rules', in H. LaFollette (ed.), Ethics in practice: An anthology, pp. 480-486, Blackwell, Cambridge, M.A.

Reese, W.L., 1980, Dictionary of philosophy and religion, Humanities Press, Atlantic Highlands, N.J.

Spence, E.H. Miller S. \& Roberts, P., 2005, Corruption and anti-corruption: A philosophical approach, Pearson/Prentice Hall, Upper Saddle River, N.J.

Stoker, H.G., 1967, Oorsprong en rigting, vol. 1, Tafelberg Publishers, Cape Town.

Stoker, H.G., 1970, Oorsprong en rigting, vol. 2, Tafelberg Publishers, Cape Town.

Van der Walt, B.J., 2003, Understanding and rebuilding Africa, Institute for Contemporary Christianity in Africa, Potchefstroom.

Vorster, J.M., 2012, 'Managing corruption in South Africa: The ethical responsibility of churches', Scriptura 109, 133-147.

Wallace, R., 2012, The deontic structure of morality, viewed 16 May 2013, from http:// philosophy.berkeley.edu/file/2/Deonticstructure-final.pdf

World Bank, 1997, 'Helping countries combat corruption - The role of the World Bank', viewed 16 May 2013, from http://www1.worldbank.org/publicsector/ anticorrupt/corruptn/corrptn.pdf 